\title{
Multi-model photogrammetric analysis of the 1990s surge of Sortebræ, East Greenland
}

\author{
Hester Jiskoot, ${ }^{1 *}$ Asger Ken Pedersen, ${ }^{2,3}$ Tavi Murray ${ }^{1}$ \\ ${ }^{1}$ School of Geography, University of Leeds, Leeds LS2 977, England \\ ${ }^{2}$ Geologisk Museum, Øster Voldgade 5-7, DK-1350 Copenhagen, Denmark \\ ${ }^{3}$ Danish Lithosphere Centre, Øster Voldgade 10, DK-1350 Copenhagen, Denmark
}

\begin{abstract}
Sortebræ is a surge-type tidewater glacier complex draining southeastward from the Geikie Plateau, East Greenland. Sortebræ's main flow unit surged around 1950 and again between 1992 and 1995. The 1990s surge affected the lower $50 \mathrm{~km}$ of Sortebræ over an area of approximately $335 \mathrm{~km}^{2}$. Over a period of $<1$ year the tidewater front advanced $>5 \mathrm{~km}$. Surge velocities in the order of kilometres per annum are about $100-$ fold the quiescent velocities. Multi-model photogrammetric analysis shows a thinning of the reservoir zone of up to $219 \mathrm{~m}$ and thickening of the receiving zone of up to $74 \mathrm{~m}$. The surge transported approximately $18.6 \mathrm{~km}^{3}$ of ice down-glacier. The total calving volume as a result of the surge amounted to $11.7 \mathrm{~km}^{3}$, equivalent to a calving flux of $3.9-7.3 \mathrm{~km}^{3} \mathrm{a}^{-1}$. The surge characteristics and environmental setting suggest that the surge mechanism involves a switch in the subglacial drainage. This surge of Sortebræ is more similar to the fast, short Alaskan-type surges than to the sluggish, long Svalbard-type surges.
\end{abstract}

\section{INTRODUCTION}

The behaviour of Greenland's surge-type glaciers is inadequately documented, and quantitative surge data are particularly sparse for this region (e.g. Reeh and others, 1994; Joughin and others, 1996; Mohr and others, 1998). In central East Greenland, at least 26 glaciers show morphological evidence of surge behaviour, yet only four surges have been observed (Weidick, 1988). Glaciological studies in this region are lacking, and few ground-based observations are available (e.g. Olesen and Reeh, 1969, 1973; Brooks, 1979; Weidick, 1988). The study of glacier surging is important to an understanding of fast glacial flow and flow instabilities, and for the prediction of catastrophic calving events and outburst floods. In this paper we present the surge history and behaviour of the Sortebræ complex between 1933 and 1996 as reconstructed from a variety of remotely sensed data, including aerial photographs, small-frame airborne photographs and a number of Landsat and European Remote-sensing Satellite synthetic aperture radar (ERS SAR) images. Quantitative observations of vertical displacement and redistribution of ice volume during the most recent surge (1992-95) were made using multi-model photogrammetric analysis of aerial photographs from 1981 and small-frame airborne photographs from 1994 and 1995. The aims of these photogrammetric measurements and observations are to:

1. quantify vertical and horizontal movements that take place during the surge;

\footnotetext{
* Present address: Department of Geography, University of Calgary, 2500 University Drive NW, Calgary, Alberta T2N 1N4, Canada.
}

2. quantify the redistribution and changes in ice volume resulting from the surge;

3. quantify the ice calving in excess of the quiescent rate and estimate calving fluxes associated with the surge;

4. identify changes in surface features and crevassing associated with the surge;

5. identify changes in the glacier hypsometry resulting from the surge.

With these data on Sortebræ's surge we contribute quantitative information on surges in Greenland and additionally provide information on specific discharge properties of surging tidewater glaciers. The analysis in this paper predates that in a companion paper (Murray and others, in press) concerning the ice dynamics during the 1990s surge of Sortebræ using intensity tracking, interferometry and visual interpretation of ERS SAR images.

\section{LOGATION AND ENVIRONMENTAL SETTING OF SORTEBRÆ}

Sortebræ $\left(68^{\circ} 45^{\prime} \mathrm{N}, 27^{\circ} 05^{\prime} \mathrm{W}\right)$ is a surge-type tidewater glacier complex in central East Greenland draining from the Geikie Plateau into a Blosseville Kyst fjord between Kap Savary and Kap Daussy (Fig. 1). Sortebræ consists of two confluent valley glaciers: Sortebræ and Sortebræ West (the names used to describe the different flow units of Sortebræ in this paper are unofficial). Sortebræ is the main branch and has a compound accumulation area, draining southwards from the plateau (2650 $\mathrm{m}$ a.s.l.) through two narrow valleys (Upper and Lower Loop Basin). From the northwest, Sortebræ is fed through a number of cirque-like accumulation basins with maximum elevations of $2000 \mathrm{~m}$ a.s.l. Several tributaries join Sortebræ's south-southeast-flowing trunk. The 


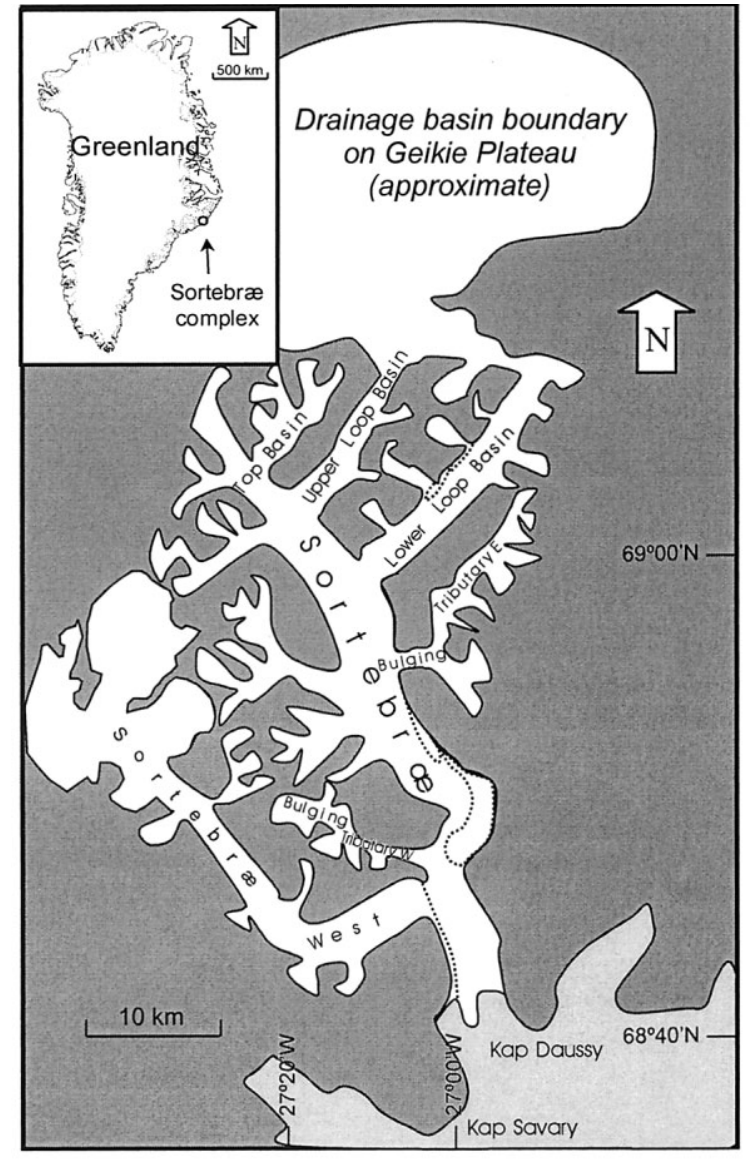

Fig. 1. Location map of the Sortebra complex, based on the available 1:100 000 topographic maps of the pre-surge geometry (GEUS, 1996).

delineation of Sortebræ's drainage-basin boundary on the plateau proves problematic. Aerial photographs and satellite images suggest that approximately $400 \mathrm{~km}^{2}$ of Sortebræ's total area of $850 \mathrm{~km}^{2}$ is located on the plateau. This area excludes Sortebræ West $\left(\sim 250 \mathrm{~km}^{2}\right)$ and Bulging Tributary East $(\mathrm{E})$ and West $(\mathrm{W})\left(\sim 60 \mathrm{~km}^{2}\right)$, as these are inferred to have separate flow regimes. A.-M. Nuttall (personal communication, 1997) estimated the area of the entire Sortebræ complex as $855 \mathrm{~km}^{2}$ using Landsat images. The difference between these area estimates arises from a discrepancy in the delineation of the drainage-basin boundary on the Geikie Plateau.

Sortebræ's overall pre-surge length was $\sim 65 \mathrm{~km}(1981)$ and its calving front was $4 \mathrm{~km}$ wide. At about $18 \mathrm{~km}$ inland from Kap Savary, Sortebræ West is confluent with Sortebræ at an almost perpendicular angle. Other glaciers in the Blosseville Kyst region vary from small cirque glaciers to large transection and valley glaciers. All outlet glaciers draining from the Geikie Plateau are deeply incised into the Tertiary plateau basalts (Pedersen and others, 1997). The quantity of supraglacial moraine material on Sortebræ and surrounding glaciers suggests that substantial subaerial erosion and weathering of the geological outcrops takes place (Brooks, 1979).

\section{SURGE HISTORY OF THE SORTEBRÆ COMPLEX}

The earliest available images of Sortebræ, 1933 aerial photographs (Gabel-Jørgensen, 1940), cover the lower and middle basins of the glacier. These show a relatively inactive glacier with few surface crevasses and a number of elongated moraine loops in the middle basin. Sortebræ West protruded with a large moraine loop into Sortebræ (Fig. 2). The glacier complex terminated about $1 \mathrm{~km}$ inland from Kap Daussy. The character of the elongated moraines indicates that Sortebræ is surge-type and surged some time before 1933.

Vertical and oblique aerial photographs from August 1943 show a smooth, partly snow-covered upper basin of Sortebræ and occasional pitting (cf. Sturm, 1987), which is characteristic of Greenland surge-type glaciers in quiescence (Weidick, 1988). All major tributaries formed protruding moraine loops onto the trunk of Sortebræ. Most medial and lateral moraines stood as prominent ridges above the glacier surface, indicating depletion. In contrast, Sortebræ West was completely crevassed. Whereas Sortebræ's calving front retreated approximately $1.5 \mathrm{~km}$ overall between 1933 and 1943, Sortebræ West advanced approximately $10 \mathrm{~km}$ into the fjord, obstructing the lower $9 \mathrm{~km}$ of Sortebræ and occupying the southern $4.5 \mathrm{~km}(\sim 90 \%)$ of the calving cliff. There are two possible explanations for the behaviour of Sortebræ West: the glacier is (1) a fast-flowing glacier or (2) of surge type. If Sortebræ West were of surge type, its surges would alternate with those of Sortebræ, and its velocity would be variable. Some difference in velocity can be observed between the period 1933-43 and the 1990s; in the former period it is in the order of $1 \mathrm{~km} \mathrm{a}^{-1}$, and in the latter it is only up to $0.35 \mathrm{~km} \mathrm{a}^{-1}$ halfway up the glacier, decreasing to almost zero at the confluence with Sortebræ (personal communication from H. Pritchard, 2000; from January 1996 SAR interferometry). However, it is more likely that Sortebræ West is a fast-flowing glacier, occasionally blocked by the surges of Sortebræ. Findings on this glacier are, however, inconclusive due to the timing of the available data.

By 1950, a dramatic change had taken place in Sortebrae, as the glacier showed extensive crevassing from the loop basins to the terminus. The same reach also showed active marginal shear zones and turbid lakes on the vertical and oblique aerial photographs taken in August 1950. Medial moraines were displaced dramatically, and moraine loops showed typical tear-shaped elongation. Sortebræ's irregular terminus had advanced to the mouth of the fjord and was actively calving. This evidence suggests that a surge took place just prior to August 1950. Bulging Tributary E also showed widespread crevassing, while strandlines of old ice surface in its upper regions indicate a drop in ice surface in the order of $\sim 100 \mathrm{~m}$. Secondary tributaries to this glacier showed extensional crevasse patterns typical for tributaries sheared off by a surging trunk. Bulging Tributary E protruded onto Sortebræ over a distance of about $2.5 \mathrm{~km}$; its moraine loop was elongated downstream due to the trunk's surge, and concertina folds indicate compression. Clearly, Bulging Tributary E also surged prior to 1950. This surge must have started before the surge of Sortebræ's trunk, as there was no evidence for Bulging Tributary E having been sheared off.

Between 1950 and 1981 Sortebræ retreated about 8 km (Fig. 2). Vertical aerial photographs of 1981 show Sortebræ's flow unit occupying one-third of the calving front and producing turbid fjord waters. Sortebræ produced many small icebergs in comparison to the few larger ones calving from nearby glaciers. By 1981 Sortebræ West's crevasses were closing, and locally formed pits. Likewise, Sortebræ was pitted in its upper reaches, and Bulging Tributary E appeared inactive and pitted.

The position and surface characteristics of Sortebræ did not change significantly between 1981 and 1992 (a Landsat image). However, the 1987 aerial photographs show Bulging Tributary W protruding with a loop into the trunk of Sorte- 

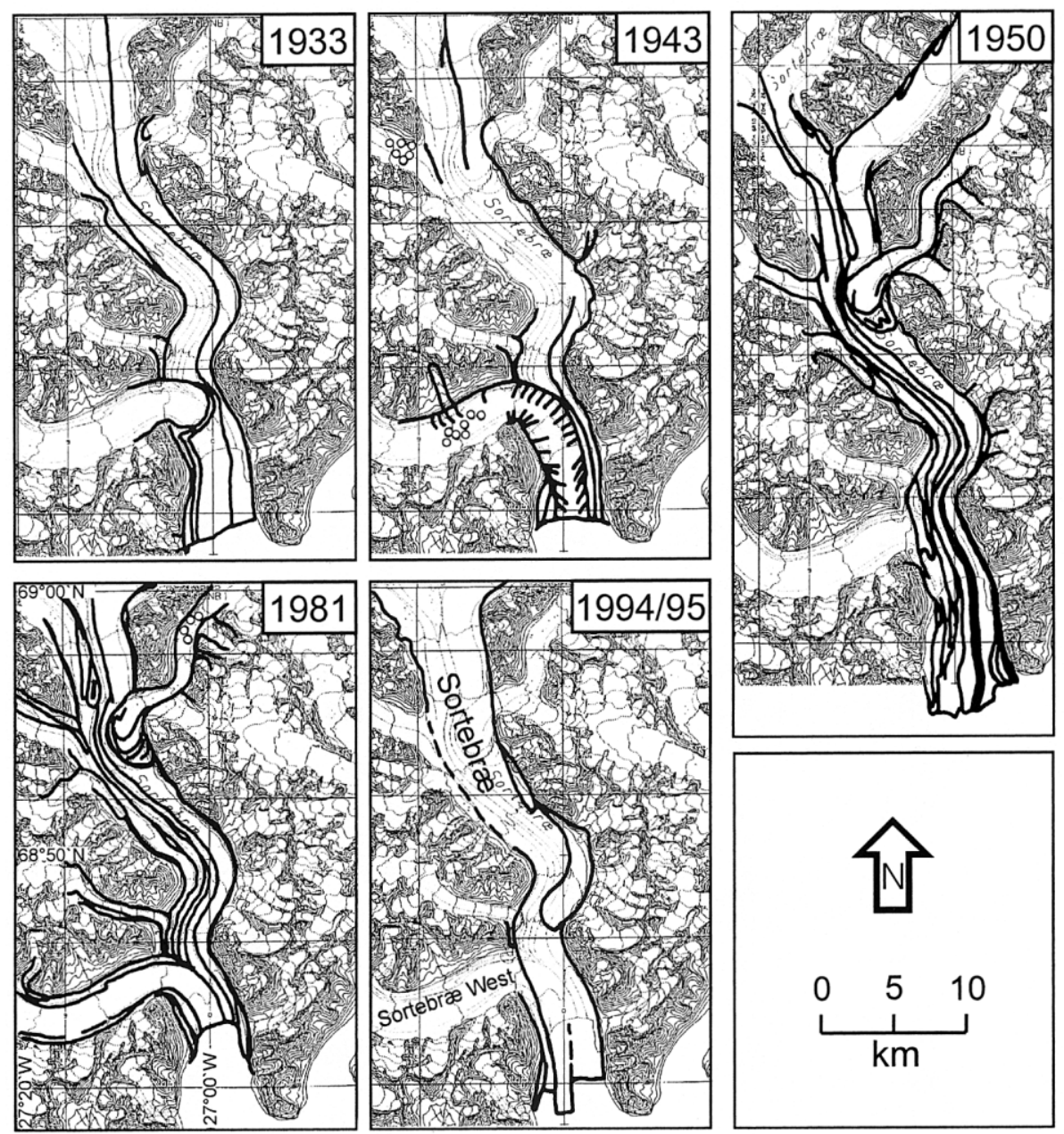

Fig. 2. The configuration of surface markers (moraines and crevasses) in the lower regions of Sortebre and Sortebre West in 1933, 1943, 1950, 1981 and 1994/95. Circles indicate surface pitting. The larger area covered in 1950 is due to better aerial photograph coverage. Base map topography is from the 1:100 000 topographic maps (C GEUS, 1996) with $100 \mathrm{~m}$ contour interval.

bræ, and a small tributary opposite Bulging Tributary W appeared crevassed. These two tributaries possibly surged some time between 1981 and 1987.

During August 1994 and July 1995, the Danish Lithosphere Centre (DLC) carried out two airborne stereophotography expeditions to the Blosseville Kyst region between Kangerlussuaq and Scoresby Sund $\left(66-70^{\circ} \mathrm{N}\right)$ (Pedersen and others, 1997). Strips of overlapping photographs of geological sections of the mountainsides were taken from a Twin-Otter plane, providing near-horizontal stereographic coverage of long sections of terrain. Photographed geological sections were preferentially oriented perpendicular to the coast along the major glaciers, and hence reveal the lateral parts of these glaciers. Sortebræ was observed to have very different surface characteristics from the surrounding glaciers (personal communication from L. M. Larsen, 1996). The glacier appeared completely crevassed and all moraine loops were elongated. A dramatic surface downdraw took place in the upper reaches of the glacier, and the glacier complex had advanced considerably (Fig. 2); Sortebræ therefore appears to have undergone a major surge between 1992 and 1995.

The above evidence shows that two major surges took place in the Sortebræ complex: one in the 1950s and one in the 1990s. The 1950s surge phase could have been of any length between 1 year or less (onset just prior to August 1950) and up to 7 years (onset just after the 1943 photos). From the 1950 photos it is not clear whether the glacier is in late surge or early quiescence. We infer that the quiescent phase must have started well after 1943, but not long after 1950, and quiescence terminated in 1992 or 1993 . Hence, Sortebræ has a quiescent period of 39-49 years, with the most likely value towards the lower end of this range. Estimates of the 1990s surge duration are more accurate due to the available ERS SAR imagery. Visual interpretation of SAR images shows that the last pre-surge image is from 30 September 1992, and the first surge image is from 20 October 1993, while SAR interferometry shows that the last surge image is from 27 May 1995 and the first post-surge image is from 8 September 1995 (Murray and others, in press). The estimated surge-phase duration is therefore 19-35 months. By 1994 the lower (pre-surge) $53 \mathrm{~km}\left(335 \mathrm{~km}^{2}\right)$ of Sortebræ was affected by the surge. During the surge, Sortebræ advanced $>5 \mathrm{~km}$ into the fjord, adding an area of approximately $26 \mathrm{~km}^{2}$ to the glacier (Fig. 2). After this advance, the northern part of the calving margin retreated rapidly. Because of the excellent quality of the DLC 1994 and 1995 stereo-photographs, we quantified the effects of the surge using multi-model photogrammetry.

\section{MULTI-MODEL PHOTOGRAMMETRY}

Multi-model photogrammetry enables precise three-dimensional measurements to be made from a series of oblique to semi-horizontal small-frame stereo-photographs, or diapositives, and conventional vertical aerial photographs. The technique was developed jointly by the Institute of Surveying and 
Table 1. Errors (in metres) determining the accuracy of vertical measurements with the DSR15 photogrammetric plotter for 10 times magnification

Photograph scale

$\leq 1: 150000 \leq 1: 40000 \leq 1: 10000$

\begin{tabular}{llll}
\hline Absolute instrument error $^{*}(\mathrm{~m})$ & 2.00 & 0.53 & 0.13 \\
Triangulation error (scale-dependent) & 2.00 & 0.53 & 0.13 \\
Floating mark error of $0.5 \mathrm{~mm}{ }^{*}$ & 5.00 & 1.33 & 0.33 \\
Human error of $0.3 \mathrm{~mm}$ & 4.50 & 1.20 & 0.30 \\
Total error $(\mathrm{m})$ & 7.30 & 1.95 & 0.49 \\
\hline
\end{tabular}

Note: Errors marked $*$ are scale-limited errors and have been multiplied by $2 / 3$ to approximate random errors in order to calculate the total error.

Photogrammetry (ISP), Technical University of Denmark, and the U.S. Geological Survey, Denver (Pillmore and others, 1981). The multi-model stereo restitution is accomplished through the simultaneous orientation of many photos in an analytical plotter by means of a block bundle adjustment, creating a coherent "multi-model block" (Dueholm, 1990). The operator then has the perception of one coherent stereoscopic model while moving between different types of photos of the terrain (Dueholm, 1992). For this study, up to 40 small-frame photographs (20 stereo-images) and 4 aerial photographs were used per multi-model block, covering approximately $20-25 \mathrm{~km}$ of terrain. Several blocks were set up at the same time to obtain full coverage of Sortebræ. Measurements in the multi-models were made by positioning an illuminated floating mark, whose position in ground coordinates was continuously monitored.

Triangulation of the small-frame photos was accomplished through transfer of aerotriangulated control points from the 1981 vertical aerial photographs, which were obtained by the Danish Cadastral Survey (KMS). The minimum number of control points is one per stereo-model plus two additional ones for each multi-model block (Dueholm, 1992). The stereo-photographs for this study were taken by one of the authors (A.K.P.) with three calibrated hand-held analogue cameras of the type Yashica FX-3 super 2000 with fixed lenses 28 or $35 \mathrm{~mm}$ Carl Zeiss Distagon. Errors due to image distortion and inner orientation are negligible. For calibration details see Dueholm (1992). An aircraft flying at a typical speed of $200 \mathrm{~km} \mathrm{~h}^{-1}$ was used as an airborne platform (Larsen and others, 1995), and an 80\% photograph overlap was used (cf. Dueholm, 1992).

\section{Measurement procedure and accuracy}

For the multi-model photogrammetric analysis of Sortebræ we used a Kern DSR15 analytical plotter, with a possible 20 times magnification. A combination of vertical aerial photographs at scale 1:150 000 from 1981, and 1994/95 stereo smallframe near-horizontal aerial photographs at different scales were used. The majority of the stereo photographs are at scales 1:10000 in the foreground, and the remainder are at scales up to approximately 1:40000. Registration of the coordinates of the floating mark enabled us to compare subsequent coordinates and measure distances between them with high accuracy. The main measurable features were vertical distances between pre-surge strandlines of ice (approximately 1992) and the 1994/95 glacier surface. At other locations, elevation differences between the 1981 glacier surface and that of 1994/95 could be measured for
Table 2. Multi-model photogrammetric measurements of surface downdraw and uplift $(\Delta H)$ and of volume gain and loss for specific zones $(\Delta V)$

\begin{tabular}{|c|c|c|c|c|c|c|}
\hline Point & $\Delta H$ & $\operatorname{Error}_{\Delta H}$ & Zone & Area & $\Delta V$ & Error $_{\Delta \mathrm{V}}$ \\
\hline & $\mathrm{m}$ & $\mathrm{m}$ & & $\mathrm{km}^{2}$ & $\mathrm{~km}^{3}$ & $\mathrm{~km}^{3}$ \\
\hline 1 & -46 & 0.7 & 1 & 18.8 & -0.26 & 0.03 \\
\hline 2 & -51 & 0.7 & 2 & 1.3 & -0.06 & 0.00 \\
\hline 3 & -37 & 0.7 & 3 & 1.3 & -0.05 & 0.00 \\
\hline 4 & -72 & 0.7 & 4 & 3.1 & -0.23 & 0.01 \\
\hline 5 & -84 & 0.7 & 5 & 2.5 & -0.21 & 0.01 \\
\hline 6 & -89 & 0.7 & 6 & 2.5 & -0.22 & 0.01 \\
\hline 7 & -107 & 0.7 & 7 & 3.8 & -0.40 & 0.02 \\
\hline 8 & -121 & 0.7 & 8 & 7.5 & -0.90 & 0.05 \\
\hline 9 & -118 & 0.7 & 9 & 7.5 & -1.00 & 0.09 \\
\hline 10 & -68 & 0.7 & 10 & 3.8 & -0.26 & 0.01 \\
\hline 11 & -85 & 0.7 & 11 & 2.3 & -0.19 & 0.01 \\
\hline 12 & -103 & 0.7 & 12 & 1.5 & -0.15 & 0.01 \\
\hline 13 & -78 & 0.7 & 13 & 2.3 & -0.15 & 0.01 \\
\hline 14 & -40 & 0.7 & 14 & 3.0 & -0.12 & 0.01 \\
\hline 15 & -115 & 0.7 & 15 & 3.0 & -0.34 & 0.02 \\
\hline 16 & -105 & 0.7 & 16 & 2.3 & -0.24 & 0.01 \\
\hline 17 & -62 & 0.7 & 17 & 2.3 & -0.17 & 0.01 \\
\hline 18 & -11 & 0.7 & 18 & 14.1 & -0.95 & 0.16 \\
\hline 19 & -26 & 0.7 & 19 & 4.4 & -0.19 & 0.02 \\
\hline 20 & -147 & 10 & 20 & 9.4 & -0.69 & 0.04 \\
\hline 21 & -56 & 3 & 21 & 6.3 & -0.35 & 0.02 \\
\hline 22 & -92 & 0.7 & 22 & 10.9 & -0.71 & 0.05 \\
\hline 23 & -45 & 3 & 23 & 12.0 & -0.78 & 0.13 \\
\hline 24 & -17 & 0.7 & 24 & 12.5 & -2.56 & 0.22 \\
\hline 25 & -76 & 0.7 & 25 & 18.8 & -1.56 & 0.10 \\
\hline 26 & -28 & 3 & 26 & 12.5 & -0.91 & 0.07 \\
\hline 27 & -51 & 0.7 & 27 & 26.6 & -1.43 & 0.15 \\
\hline 28 & -130 & 10 & 28 & 20.0 & -0.49 & 0.03 \\
\hline 29 & -219 & 10 & 29 & 15.8 & -0.60 & 0.03 \\
\hline 30 & -191 & 10 & 30 & 16.9 & -0.48 & 0.05 \\
\hline 31 & -60 & 0.7 & 31 & 9.4 & -0.24 & 0.01 \\
\hline 32 & -109 & 0.7 & 32 & 42.5 & +3.14 & 0.47 \\
\hline 33 & -32 & 0.7 & 33 & 23.8 & +1.00 & 0.35 \\
\hline 34 & -31 & 3 & 34 & 1.6 & +0.51 & 0.03 \\
\hline 35 & -47 & 3 & 35 & 8.6 & +3.01 & 0.17 \\
\hline
\end{tabular}

Notes: For each volume-loss measurement, $10 \%$ was added to represent volume due to opening of crevasses. Points 1-32 were measured from August 1994 photographs, and points 33-52 from July 1995 photographs. For points 1-43 the pre-surge strandlines and post-surge surface on the 1994/95 images were taken as pre- and post-surge elevations, while for points 44-50 the 1981 glacier surface was taken as pre-surge elevation. Points 45 and 46 are not covered by the 1994/95 stereo-images. Point 51/ 52 is the height difference of adjacent points 51 and 52 on the 1995 image (Fig. 6c), due to the lack of pre-surge data for this location. For location of points (1-52) and zones (1-35) see Figures 3 and 6.

the same $x$ - $y$ coordinates. A positive height difference indicates a thinning of the glacier, resulting from a volume loss in that part of the glacier. A negative height difference indicates thickening of the glacier surface, resulting from an in- 


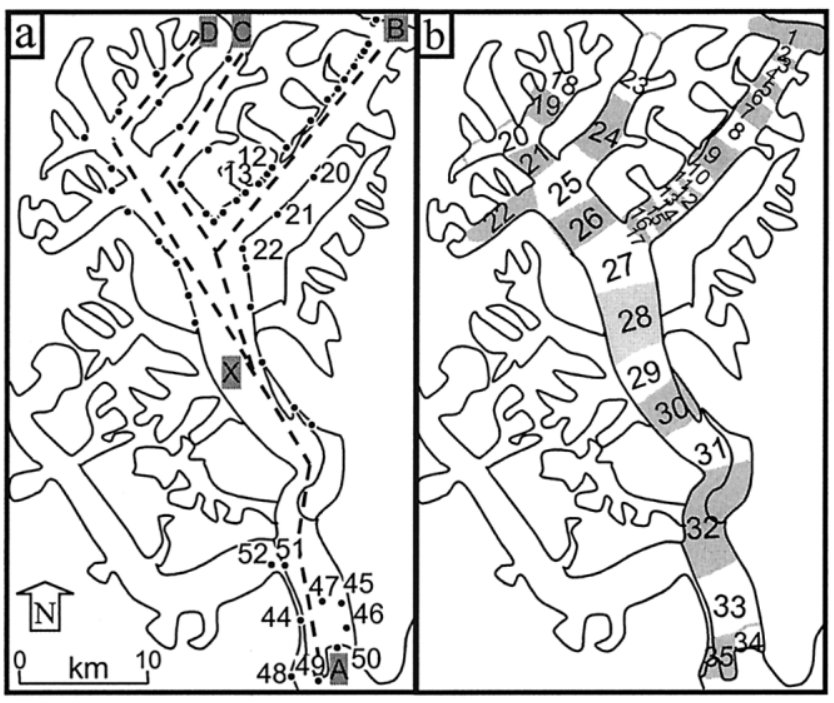

Fig. 3. (a) Location map of 52 surface downdraw and uplift measurements. Dots are measurement points, and numbers correspond to those in Table 2 and Figure 6. A, B, C, D and $X$ and dashed lines indicate approximate positions of the longitudinal transects of downdraw and uplift given in Figure 4. (b) Location map of zones of downdraw and uplift. Numbers correspond to zone numbers in Table 2.

crease in ice volume. In addition, the height and position of the calving margin were measured, as well as dimensions of surface features such as lakes and crevasses.

The measurement accuracy using the Kern DSR15 depends on (1) the photograph scale, (2) the quality of control points and triangulation, (3) the scale-limited error of the floating mark and (4) the operator error (Dueholm, 1992; Dueholm and Pedersen, 1992). The combined error in measurement points, distances and volume displacement was estimated using standard techniques (e.g. Squires, 1976, p. 36). The absolute vertical errors for a 10 times magnification at three different photoscales in the multi-model are listed in Table 1. (Note that these errors concern the relative height measurements and not the absolute elevation.) These errors were used for the point measurements in Table 2. Because each measurement of thinning or thickening $(\Delta H)$ is based on two independent measurements, the errors in $\Delta H$ are a combination of the errors in these two measurements (these were occasionally taken from photos at different scales).

Vertical displacement $(\Delta H)$ was measured for 52 locations (Fig. 3a). Displacement of ice volume was measured by dividing the glacier into 35 zones (Fig. $3 \mathrm{~b}$ ) of different areas $(A)$ and calculating average thinning or thickening $\left(\Delta H_{\mathrm{A}}\right)$ for each zone by taking the average $\Delta H$ values of measured locations within that zone. Zones were outlined to contain between one and four measurements. Point and zone measurements are given in Table 2. Because of the orientation of a number of the smaller-scale photos, namely, those looking upstream in the upper basins, accurate measurements could only be taken for points in the foreground. These points were more drawn down than points in the background of the image, and therefore represent a maximum thinning for a zone. Furthermore, the glacier surface appeared wavy in certain locations after the surge (Fig. 6b, shown later). Two measurements just downstream of Bulging Tributary E were taken in the wave troughs and are therefore not representative of average thinning. Hence, in 6 of the 35 zones we introduced an ad hoc correction factor of 0.5 for 9 of the 52 point meas- urements. This correction resulted in the reduction of total volume loss from the reservoir zone by $10 \%$.

\section{QUANTITATIVE OBSERVATIONS OF THE 1990s SURGE}

\section{Depression, uplift and ice-volume displacement}

Depression of the glacier surface, measured using multimodel photogrammetry, varied between 11 and $219 \mathrm{~m}$, with the maximum occurring in the Loop Basins (see Table 2). A transect of thinning and thickening in the Lower Loop Basin (Fig. 4) shows that the lowering of the glacier surface generally decreases down-glacier to a "zero point" upstream of Bulging Tributary W, below which the glacier thickens. Thickening of the lower glacier is $24-74 \mathrm{~m}$ (Table 2). This, however, is a minimum estimate based on elevation differences between the 1981 and 1995 glacier surface, and it is uncertain how much post-1981 thinning (if any) took place before surge initiation. The heights of the pre- and postsurge calving cliff are similar and in the range $25-60 \mathrm{~m}$.

For a realistic estimation of total ice-volume displacement as a result of the surge, a number of assumptions had to be made before calculating displacement in the 35 designated zones (Fig 3b). These assumptions are necessary, but they could result in over- or underestimation of stored ice volumes in the reservoir and receiving zones. We assume that:

1. The glacier surface cross-section is flat rather than convex or concave.

2. No ice-volume redistribution occurred in the period 1994-95, and locations where post-surge measurements were taken had experienced their maximum downdraw.

3. There is a maximum 5\% error in the zone area calculation. This is based on the accuracy of zone measurement using maps at scale 1:100 000 .

4. Sortebræ's calving cliff is grounded at approximately $300 \mathrm{~m}$ below sea level. This is based on linear extrapolation of bathymetric measurements (Brooks, 1979; Escher and Pulvertaft, 1995). For every $100 \mathrm{~m}$ thicker or thinner ice in zones 34 and 35 (Table 2) the calving volume will decrease or increase by $1 \mathrm{~km}^{3}$.

5. Volume correction for crevassed areas is an average $10 \%$ increase in ice porosity (cf. Raymond, 1987). Hence, the volume of ice transported down-glacier increases.

6. Release of subglacially stored water or closing of subglacial cavities does not contribute to the overall downdraw of the glacier surface (cf. Kamb and others, 1985). The error margins in our study are larger than the possible error introduced by this assumption: a continuous ice-bed gap of $1 \mathrm{~m}$ under the reservoir zone would accommodate only $0.26 \mathrm{~km}^{3}$ of ice.

7. The surface downdraw in the reservoir zone is not preceded by a surface uplift as a result of the passage of the surge front (cf. Meier and Post, 1969; Dolgoushin and Osipova, 1975; Murray and others, 1998), as no systematic difference between the 1981 surface and 1994/95 strandlines was measured.

Using the above assumptions it was calculated that an ice volume of $18.6 \pm 0.4 \mathrm{~km}^{3}$ was discharged from the reservoir zone, of which $2.6 \mathrm{~km}^{3}$ was due to increased porosity. Of this discharged ice, $6.9 \pm 0.6 \mathrm{~km}^{3}$ was stored in the receiving 


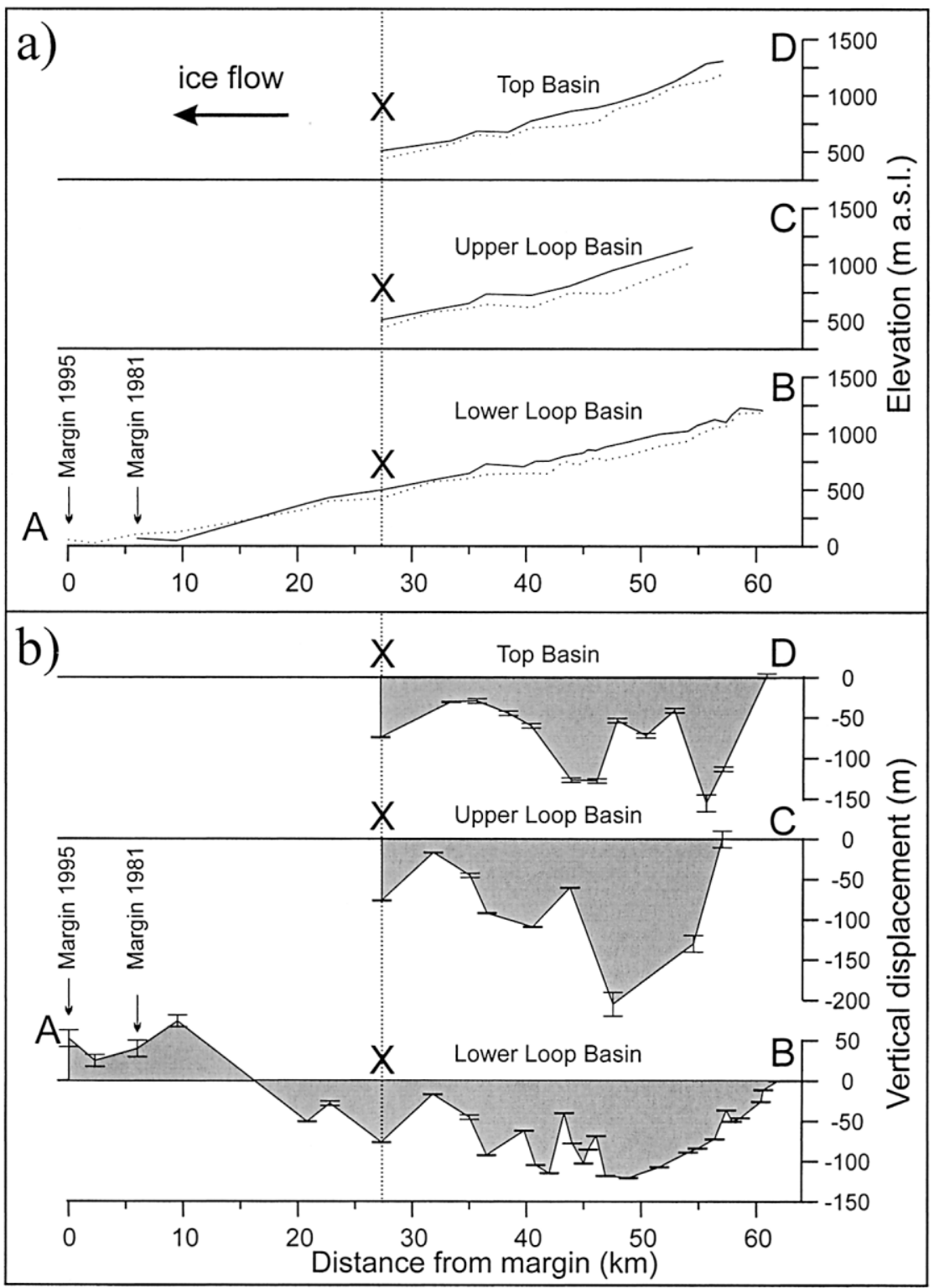

Fig. 4. Three transects of (a) pre-surge (solid line) and post-surge (dotted line) surface elevation, and ( $b$ ) surface downdraw and uplift as a result of the surge. Locations of transects and $A-D$ and X are shown in Figure 3. All transects have in common section $A-X$, which is only plotted in full for the Lower Loop Basin transect. Bars in (b) indicate error margins in the measurement points.

zone in August 1995, and the remaining volume $(11.7 \pm 0.7$ $\mathrm{km}^{3}$ ) must have been calved into the fjord or melted. The errors in the volume calculations include all the errors due to assumptions 3 and 5 above, as well as the errors in height measurement (Table 2). Since there are large uncertainties in the remainder of the assumptions, as well as in the estimate of the surge advance and in the areal extrapolation from point measurements, the error in the calculated volume is possibly much larger than given above.

Due to the uncertainty in the duration of the surge phase, the annual calving flux is estimated between $3.9 \pm 0.2 \mathrm{~km}^{3} \mathrm{a}^{-1}$ for a 36 month surge duration and $7.4 \pm 0.4 \mathrm{~km}^{3} \mathrm{a}^{-1}$ for a 19 month surge duration. These values are about one-quarter of the calving rate of Greenland's most productive calving glacier, Jakobshavn Isbræ, and about half of that of Storstrømmen in surge (Reeh and others, 1994). The pre-surge calving flux, based on ice-flow velocities and calving-front characteristics in 1981, was $0.02-0.16 \mathrm{~km}^{3} \mathrm{a}^{-1}$.

\section{Observed velocities}

By tracking points on two surface moraines between subse- quent aerial photographs, we derived estimates for Sortebræ's velocities. The estimated quiescent velocity in the upper region for the period $1933-43$ is $175 \pm 50 \mathrm{~m} \mathrm{a}^{-1}$ and for $1981-87$ is only $7.5 \pm 2.5 \mathrm{ma}^{-1}$, while for the middle region it is $200 \pm 50$ and $75 \pm 50 \mathrm{~m} \mathrm{a}^{-1}$, respectively. Surge velocities, measured from moraine-loop displacement and frontal advance in the period 1991-95, are estimated to be in the range $625-2500 \mathrm{~m} \mathrm{a}^{-1}$ in the upper region and $1700-$ $10000 \mathrm{~m} \mathrm{a}^{-1}$ in the middle and lower regions of Sortebræ. The latter is a minimum estimate disregarding calving. These measurements imply a minimum 4-fold and a maximum 300-fold increase of flow velocity from quiescence to surge. Sortebræ's quiescence velocities are in the range found for other (possibly surge-type) tidewater glaciers in East Greenland (e.g. Dwyer, 1995) but are five to ten times lower than those measured on tidewater outlets at the head of Nordvestfjord, Scoresby Sund (Olesen and Reeh, 1969, 1973). Murray and others (in press) give a detailed account of the spatial and temporal variability of Sortebræ's surface motion using ERS SAR interferometric and tracking techniques.

The propagation velocity of the surge front is important for estimates of surge duration and for comparison of surge char- 
acteristics worldwide. By assuming volume conservation, we calculated the propagation velocity of a surge front, $w$, from:

$$
w=\frac{u_{2} h_{2}}{h_{2}-h_{1}},
$$

where $u_{2}$ is the horizontal surge velocity and $h_{2}$ and $h_{1}$ are the average post-surge and pre-surge thickness of the glacier, respectively (Raymond and others, 1987). There are no direct measurements of glacier thickness for Sortebræ. Therefore we assume an estimated centre-line ice thickness of approximately $1 / 4$ to $1 / 8$ times the cross-sectional glacier width (for a shape factor of 0.7-0.8: Paterson, 1994). The surge-front propagation can then be calculated at locations where velocity estimates are taken and where surface uplifts are measured. For the zone starting at the confluence of Sortebræ and Sortebræ West the height difference between the surging part and the stagnant part was in the order of $53 \pm 5 \mathrm{~m}$. For a $4 \mathrm{~km}$ wide cross-section and a surge velocity of $2500 \mathrm{~m} \mathrm{a}^{-1}$ the surge-front propagation is estimated to be in the range $23725-51100 \mathrm{~m} \mathrm{a}^{-1}$ for a pre-surge glacier thickness of 500 and $1000 \mathrm{~m}$, respectively. It would thus take 1-2.5 years for the surge front to travel $53 \mathrm{~km}$ before reaching the terminus. A surge period of 19-36 months (from SAR imagery) is therefore a reasonable estimate. Note, however, that errors in these calculations are potentially very large due to the lack of glacier thickness measurements. Further, the surge could have nucleated down-glacier of the maximum elevation affected by the surge, and the surge front could have travelled both down- and up-glacier. If so, the surge front could have reached the glacier terminus in less then the estimated minimum of 1 year, and the glacier could have advanced rapidly after surge initiation.

\section{Glacier hypsometry}

Glacier hypsometry is the distribution of glacier area over elevation and is determined by valley shape, topographic relief and ice-volume distribution. Hypsometry is important for long-term glacier response through its link with mass-balance elevation distribution (Furbish and Andrews, 1984). Research by Wilbur (1988) suggests that once a glacier becomes "bottom-heavy", surge behaviour is favoured. Furthermore, a glacier surge would not result in a significant change in hypsometry, unless the surge results in a disproportionately large change in ice-volume distribution (Wilbur, 1988).

Sortebræ's pre-surge hypsometry was measured from topographic maps at scale 1:100000, which are based on 1981 aerial photographs. The post-surge hypsometry could be reconstructed from interpolating multi-model photogrammetric measurements. As with the calculation of zones in Table 2, errors in surface area for the hypsometric measurements are within 5\%. Absolute elevation measurement accuracy is generally within $10 \mathrm{~m}$, but between elevation ranges 700-1200 and $0-100 \mathrm{~m}$ a.s.l. it is up to $50 \mathrm{~m}$. The general shape of the hypsometry curves is not affected by these errors.

The general shapes of the 1981 and 1994/95 hypsometric curves are similar (Fig. 5): the upper convex curve sections (2000 and $2650 \mathrm{~m}$ a.s.l.) resemble the "ice-cap" type, while below $2000 \mathrm{~m}$ the curves resemble the "alpine-valley" types (Wilbur, 1988). Sortebræ's hypsometry is "top-heavy": the area/elevation distribution function is largest at 2400-2650 $m$ a.s.l., whilst it is smallest at a lower elevation of 1800-2000 $m$ a.s.l. This observation appears to contradict the suggestion that surge-type glaciers are commonly bottom-heavy Wilbur, 1988). However, if higher-elevation bands (on the

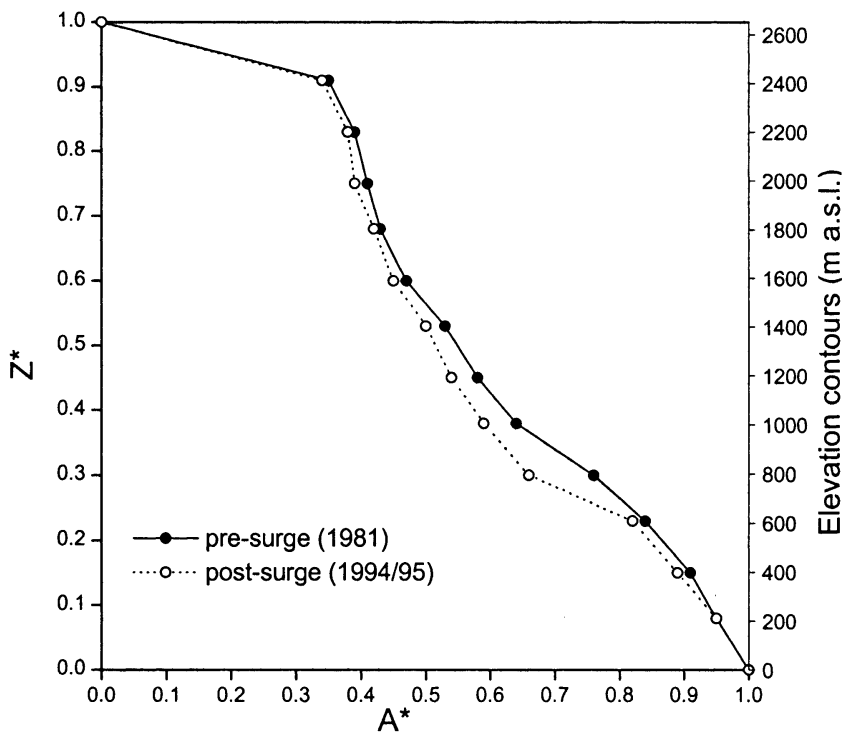

Fig. 5. Pre-surge and post-surge hypsometries of Sortebre. $A^{*}$ and $Z^{*}$ are dimensionless units for area and elevation (Furbish and Andrews, 1984). $A^{*}$ is the cumulative area above a certain elevation. At the glacier terminus $Z^{*}=0$ and at the head of the glacier $Z^{*}=1$. On the right axis the elevation is given in metres above sea level in order to facilitate interpretation of the curves.

plateau) are disregarded, the hypsometry tends to be bottom-heavy. The error in the position of the drainagebasin boundaries on the plateau is potentially very large, and it is unknown how much of this ice actively contributes to the mass balance of Sortebræ.

Even though considerable surge advance and ice transport took place, the surge of Sortebræ has clearly not affected its general hypsometry. This finding agrees with Wilbur's hypothesis for surges of large glaciers (Wilbur, 1988). However, the post-surge hypsometry is slightly more bottomheavy than before the surge, which is to be expected from a surge advance of a glacier with a low average surface slope in the region of advance.

\section{Equilibrium-line altitude and accumulation-area ratio}

From the available images between 1933 and 1995 we suggest that the end of the melt season on Sortebræ occurs between early August and early September. Assuming no superimposed ice is formed on Sortebræ, the transient snowline late in the melt season can be used as a proxy for the equilibrium-line altitude (ELA) of a glacier (Paterson, 1994). Snowlines from images in late August 1943, 1981, 1988 and 1995 give an ELA in the range $1100-1200 \mathrm{ma}$ a.s.l. Using this ELA range and the pre- and post-surge hypsometries for Sortebræ (Fig. 5), the 1981 accumulation-area ratio (AAR) is estimated in the range $0.58-0.61 \pm 0.05$, and the $1994 / 95$ AAR is in the range $0.54-0.57 \pm 0.05$. This decrease is too insignificant to suggest that Sortebræ's AAR reflects a normal trend for glaciers that have recently surged: these glaciers change from a state of positive imbalance before the surge to one of a negative imbalance after the surge. These data suggest a balance AAR of $0.56-0.59 \pm 0.05$, which coincides with the range of values found for balance AARs in subpolar regions (e.g. Dowdeswell and others, 1997). However, given the inaccuracies of the drainage-basin boundaries and elevation distribution on the plateau, this balance AAR should be taken as a first approximation. 

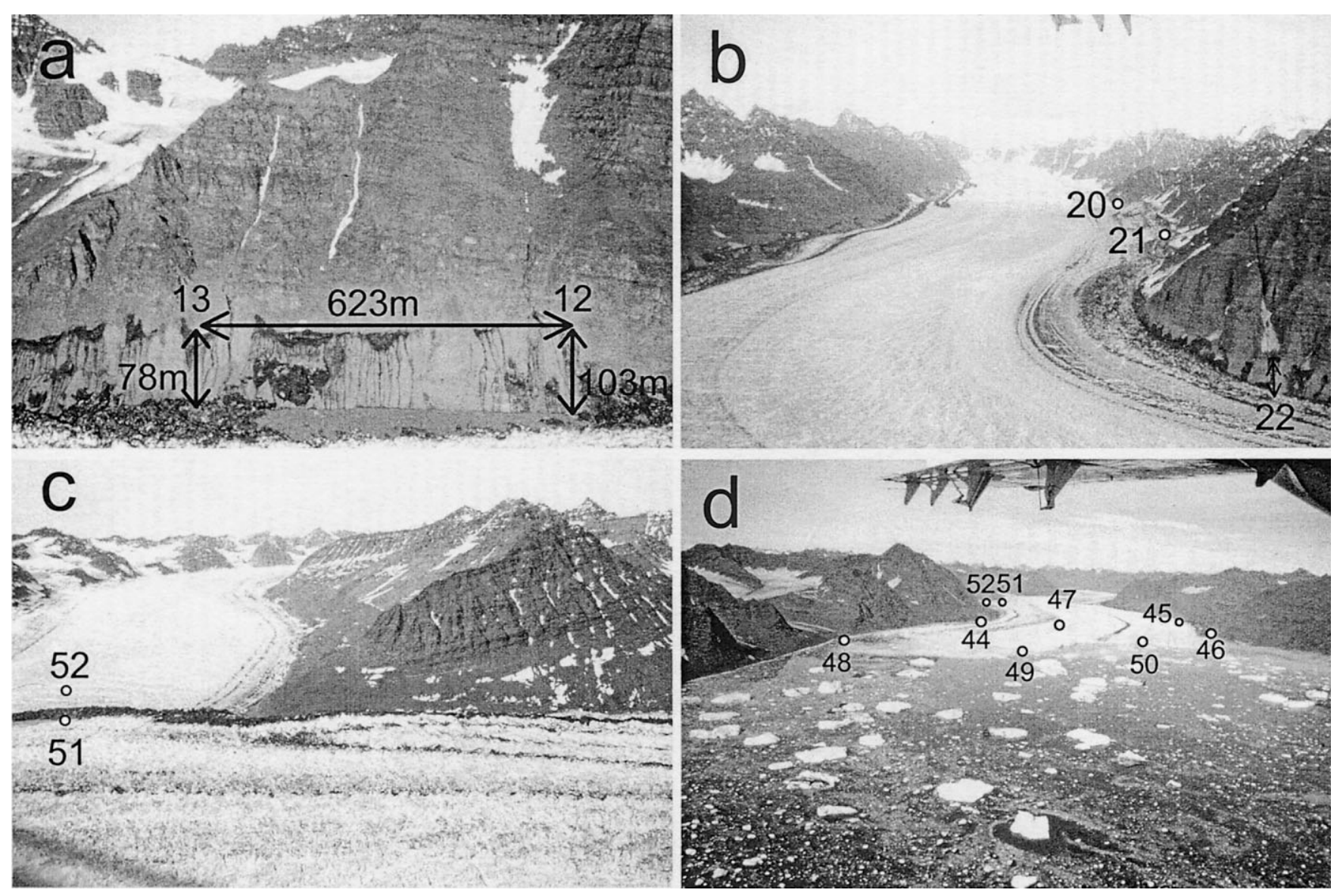

Fig. 6. Photographs of the surge of Sortebre in 1994/95 (C) DLC). Numbers indicate approximate locations of measurements with the Kern DSR15 (Fig. 3). Vertical arrows indicate height differences between the pre-surge surface (strandlines) and post-surge surface. (a) Marginal turbid lake of about $600 \mathrm{~m} \times 200 \mathrm{~m}$. (b) Waves and longitudinal crevasses in Lower Loop Basin. (c) Marginal shear zone. (d) Advanced calving margin of Sortebre, looking up-glacier. Largest tabular iceberg is about $200 \mathrm{~m}$ across.

\section{Surface features: crevasses, lakes and sediments}

The crevasse-pattern distribution over a glacier basin can inform us where a surge initiated (the "nucleus"), how the surge front propagated and about the characteristics of the transverse velocity distribution (e.g. Sharp and others, 1988; Hodgkins and Dowdeswell, 1994). Above the surge nucleus, forces are mainly extensional and crevassing is predominantly transverse. Below the surge front a combination of compression and extension takes place, causing both longitudinal and transverse crevasse types, often resulting in chaotic patterns (Lawson, 1996).

Observations on the 1994/95 crevasse distribution of Sortebræ are incomplete, as only the lateral zones of the glacier are covered: the region of the central flowline is only occasionally visible on the images. Crevasse types include transverse crevasses in the far upper basins and at the tributaries; concentric, transverse and longitudinal crevasses in the upper and middle basins; conjugate crevasses at the shear margins and at the boundaries between flow units in the middle and lower basins; and chaotic crevassing in the lower basin (Fig. 6). Crevasse patterns suggest that the surge initiated halfway down the Lower Loop Basin, migrating both up- and down-glacier.

Crevasse width in the middle and lower basin is up to tens of metres, while the lower $15 \mathrm{~km}$ of Sortebræ is broken up into rifts tens of metres in height. These crevasse-pattern types are very similar to those observed during surges of large calving glaciers such as Bering Glacier, Alaska, U.S.A., and Osbornebreen and Bodleybreen, Svalbard (Hodgkins and Dowdeswell, 1994; Molnia, 1994; Rolstad and others, 1997). However, in the lower half of the Lower Loop Basin, the post-surge surface appears wavy with a wavelength of about $2 \mathrm{~km}$ and an amplitude of about $25 \mathrm{~m}$ (Figs 4 and 6). The waves become more pronounced in a down-glacier direction. Dynamic waves with a similar frequency but double the amplitude were observed to travel down-glacier during the 1963 surge of Medvezhiy glacier, Pamir, central Asia (Dolgoushin and others, 1963), and have been explained as resulting from the passage of kinematic waves or a surge bulge. This could also be an explanation of the waves on Sortebræ.

Shearing occurred along the entire margin of the surge basin, leaving tributaries in the reservoir zone hanging and those in the receiving zone blocked. Sortebræ West and Bulging Tributary W were cut off by the surging trunk, with their surfaces about 50-70 m below that of Sortebræ (Fig. $6 \mathrm{c}$ ). The combination of marginal shear zones and a relatively flat transverse cross-section suggests that the icevelocity profile is that of block motion, which is common for surging glaciers (Kamb and others, 1985; Reeh and others, 1994). At all shear zones large amounts of sediment emerged. In 1995, fine-grained dirt cones up to $3 \mathrm{~m}$ high were observed at the northern margin of Sortebræ, which we interpret as thrust planes.

The appearance of supraglacial lakes is a common phenomenon on surge-type glaciers, although they are mostly clear and sediment-free (e.g. Lingle and others, 1993; Reeh and others, 1994). Turbid shear-zone lakes are only reported for Bering Glacier, whilst turbid water was found in crevasses on Variegated Glacier, Alaska (Kamb and others, 
1985; Molnia, 1994). On Sortebræ, turbid lakes with a high suspended sediment content developed during the surge. These have rectangular shapes with maximum dimensions of approximately $200 \mathrm{~m} \times 600 \mathrm{~m}$, with the longest axis in the direction of ice flow (Fig. 6a). The lakes mainly occur in the shear margins of the Loop Basins and in the shear zone between Sortebræ and Sortebræ West. The lakes are the first evidence of supraglacial water on Sortebræ: this water is likely to have been subglacially derived.

\section{IMPLICATIONS OF THE SURGES OF THE SORTE- BRÆ COMPLEX}

Interregional variations in surge behaviour, such as differences in surge period, surge velocity development and morphological adjustment, are particularly important in understanding flow dynamics. In order to comprehend the mechanisms of glacier surging, it is important to search for systematic differences in surge behaviour and attempt to relate these differences to, for example, environmental conditions and/or glacier morphology (e.g. Dowdeswell and others, 1991). Differences in surge duration and velocity development are suggested to result from differences in glacier size, glacier type, thermal and substrate conditions and geographical location (Meier and Post, 1969; Dowdeswell and others, 1991, 1995; Hewitt, 1998; Murray and others, 1998). Below, we systematically compare the surge of Sortebræ with other surges in Greenland as well as those in other regions. For this study a selection of sample data on active glacier surging worldwide was used (Table 3).

Sortebræ's surge velocities are of the same order as those of some of the faster surge-type glaciers (Variegated, Medvezhiy and Bering glaciers; Table 3). Its velocity difference between quiescence and surge is of the same order as that for most tidewater glaciers. The estimated ice-volume redistribution from reservoir to receiving zone $\left(18.6 \mathrm{~km}^{3}\right)$ and the frontal advance $(>5 \mathrm{~km}$ ) of Sortebræ falls into the class of large-scale surges of other calving glaciers such as Storstrømmen, northeast Greenland, and Bering Glacier (Reeh and others, 1994; Sauber and others, 1995). The surface downdraw, with maxima around $200 \mathrm{~m}$, is large compared to most other observations, but Sortebræ is unlike other glaciers in that its average thinning exceeds its thickening. This anomaly could have been caused by (1) a rapid removal of ice volume through calving prior to 1995, (2) a thickening of Sortebræ below sea level that we were unable to detect, or (3) the 1981-95 thickening being a minimum estimate because of surface melt prior to 1995.

The 1990s surge of Sortebræ resulted in a calving volume of $11.7 \mathrm{~km}^{3}$ and a calving flux of $3.9-7.3 \mathrm{~km}^{3} \mathrm{a}^{-1}$. For comparison, non-surging outlet glaciers draining from the Inland Ice into the innermost part of Scoresby Sund have calving rates of $0.2-10 \mathrm{~km}^{3} \mathrm{a}^{-1}$ (calving-front lengths around 2-6 $\mathrm{km}$ ), while in North Greenland calving rates are only in the order of $0.1-0.7 \mathrm{~km}^{3} \mathrm{a}^{-1}$ (Olesen and Reeh, 1969, 1973; Higgins, 1991). Not only has Sortebræ's calving rate increased during its surge, but the glacier also produces on average larger icebergs than during quiescence. This is in contrast to observations on Svalbard glaciers, where surges appear to reduce the size of icebergs (Dowdeswell, 1989). The calving flux calculated for Sortebræ might be indicative of that from other large surging tidewater glaciers in East Greenland (see Weidick, 1988).

According to Dowdeswell and others (1991, 1995), Svalbard surge-type glaciers are unique for the long duration of their surges (3-10 years), the long quiescent phases (50-500 years) and the low surge velocities. These characteristics have

Table 3. Surge characteristics of Sortebre and other surging glaciers

\begin{tabular}{|c|c|c|c|c|c|c|c|c|c|c|c|}
\hline \multirow[t]{2}{*}{ Glacier/breen } & Length & $\begin{array}{c}\text { Surge } \\
\text { advance }\end{array}$ & Hupper & H lower & $\begin{array}{c}\text { Volume } \\
\text { displ. }\end{array}$ & $\begin{array}{c}\text { Calving } \\
\text { rate }\end{array}$ & $\begin{array}{l}\text { Quiescent } \\
\text { velocity }\end{array}$ & $\begin{array}{l}\text { Surge } \\
\text { velocity }\end{array}$ & $\begin{array}{l}\text { Surge front } \\
\text { propagation }\end{array}$ & $\begin{array}{c}\text { Surge } \\
\text { duration }\end{array}$ & $\begin{array}{l}\text { Quiesc. } \\
\text { duration }\end{array}$ \\
\hline & $\mathrm{km}$ & $\mathrm{km}$ & $\mathrm{m}$ & $\mathrm{m}$ & $\mathrm{km}^{3}$ & $\mathrm{~km}^{3} \mathrm{a}^{-1}$ & $\mathrm{ma}^{-1}$ & $\mathrm{ma}^{-1}$ & $\mathrm{ma}^{-1}$ & years & years \\
\hline Finsterwalder ${ }^{1}$ & 12 & 1.5 & -50 & +100 & & & 13 & & & & \\
\hline Usher $^{1}$ & 12 & 1.5 & -40 & +120 & 0.82 & & & $550-1570$ & $>365$ & 8 & \\
\hline Fridtjov $^{1}$ & 13 & 2.5 & & & & & & 1250 & & $>3$ & 130 \\
\hline Bakanin $^{1}$ & 17 & 0 & -15 & +40 & $0.67^{*}$ & - & $1-5$ & $88-1100$ & $1000-1800$ & $5-10$ & $>60$ \\
\hline Osborne $^{1}$ & 20 & 2 & -100 & +100 & & & & $440-2190$ & 2190-2555 & $>3$ & \\
\hline Hinlopen ${ }^{1}$ & 68 & 3 & & & & 2 & & $5100-5800$ & & $>4$ & \\
\hline Medveziy $^{2}$ & 13 & 1.6 & -100 & +150 & 0.06 & - & $0.5-550$ & $25000-38000$ & 29000 & $0.4-1$ & $10-15$ \\
\hline Chiring $^{3}$ & 15.5 & 2.5 & -150 & +130 & $1-1.5$ & & & & & 3 & 110 \\
\hline Variegated $^{4}$ & 20 & $2-5$ & -50 & +100 & & & 75 & $5000-18000$ & 5500-29000 & 2 & 20 \\
\hline Black Rapids ${ }^{4}$ & 43 & 6.4 & +45 & -125 & & & $50-70$ & & & 1 & \\
\hline Steele $^{4}$ & 50 & 12 & -70 & +100 & & & & 6000 & & & \\
\hline Bering $^{4}$ & 200 & 9.7 & -50 & & & & 365 & $4015-12000$ & 32850 & $2-3$ & $20-30$ \\
\hline West Fork ${ }^{4}$ & 40 & & -60 & +123 & 3.7 & & 60 & 4380 & 8395 & $<1$ & 50 \\
\hline Løberen $^{5}$ & 22 & 7.5 & & & & - & & $>1000$ & & $7-15$ & $150-200$ \\
\hline Bjørnbo $^{5}$ & 35 & 10 ? & & +160 & & - & & & & $5-6$ & $>100$ \\
\hline Roslin $^{5}$ & 38 & 10 & $-?$ & $+?$ & & - & $4-10$ & & & & \\
\hline Sortebræ ${ }^{5}$ & 77 & $>5$ & -200 & +75 & 18 & $3.9-7.3$ & $7.5-175$ & $1700-10000$ & $23500-51000$ & $1.5-3$ & $40-50$ \\
\hline Storstrømmen $^{5}$ & 120 & 10 & -80 & & 50 & 10.8 & $130-300$ & $1500-2000$ & & $5-6$ & 70 \\
\hline
\end{tabular}

Notes: Glaciers are sorted by geographic region and in order of increasing length. 'Svalbard glaciers (Hagen, 1987, 1988; Hodgkins and Dowdeswell, 1994; Nuttall and others, 1997; Rolstad and others, 1997; Glasser and others, 1998; Murray and others, 1998); ${ }^{2}$ Pamir glaciers (Dolgoushin and Osipova, 1975); ${ }^{3}$ Karakoram glaciers (Hewitt, 1998); ${ }^{4}$ Alaska glaciers (Meier and Post, 1969; Stanley, 1969; Kamb and others, 1985; Lingle and others, 1993; Harrison and others, 1994; Molnia, 1994; Fleisher and others, 1995; Heinrichs and others, 1996); ${ }^{5}$ Greenland glaciers (Rutishauser, 1971; Colvill, 1984; Weidick, 1988; Reeh and others, 1994).

*Volume displacement for Bakaninbreen is estimated for the first 2 years of the surge. 
been accredited to specific substrate and thermal conditions, mass balance and rate of downdraw (Dowdeswell and others, 1991, 1995; Murray and others, 1998). Recently, Hewitt (1998) recorded that Karakoram Himalayan surge-type glaciers also have surge and quiescent phases longer than the usual 2-3 years for surge and 20-30 years for quiescence (cf. Meier and Post, 1969). Data on three glaciers in East Greenland suggest a surge duration of 5 to $>10$ years and quiescent-phase duration of 70-150 years (Rutishauser, 1971; Colvill, 1984; Weidick, 1988; Reeh and others, 1994). These values imply that surges in East Greenland are intermediate between the fast short-period surges of glaciers in Alaska and the Pamir, and the slow long-period surges common for Svalbard. Conversely, Sortebræ falls into the category of short, fast surges, with its estimated surge duration of 19-36 months and its maximum surge velocity of the order of $10 \mathrm{~km} \mathrm{a}^{-1}$. The quiescent phase of Sortebræ (40-50 years) is not significantly different from that of Alaskan surge-type glaciers. Weidick (1988) found that West Greenland seems characterized by short surges (1-2 years) and intermediate quiescent phases (30-50 years). However, there is much uncertainty associated with these data, as (1) the data were mainly based on air-photo interpretation of 11 surge-type glaciers in the Disco-Nuqssuaq area, (2) only four of these have multiple surges recorded, and (3) only one has two dated surge events (Weidick, 1988).

Statistical analysis by Dowdeswell and others (1991) indicated that glacier size is not significantly related to the duration of the active surge phase. However, thermal regime, in combination with substrate, seems to play an important role in surge propagation (Murray and others, 2000) and termination (Smith and others, in press). The only measurements on the thermal regime of central East Greenland glaciers are from boreholes drilled in Schuchert Gletscher and from radio-echo sounding measurements on Roslin Gletscher, suggesting that both Stauninger Alps glaciers are polythermal (Kirchner, 1963; Davis and others, 1973). Other valley glaciers in the Stauninger Alps are described as subpolar (Mercer, 1975). Hence, it is plausible that Sortebræ and other large central East Greenland glaciers are polythermal. Unlike the surge-type glaciers in the Stauninger Alps, which overlie metamorphic bedrock, Sortebræ overlies basalts. These Tertiary basalts, similar in origin to those in the West Greenland surge cluster (Weidick, 1988), are extrusive igneous rocks and produce fine-grained erosion products (Pedersen and others, 1997). The presence of fine-grained material on Sortebræ is clear from its emergence in the shear zones, the turbidity of supraglacial lakes and of the proglacial meltwater plumes. Furthermore, Sortebræ's termination in a fjord system suggests the presence of marine clays (Gabel-Jørgensen, 1940). It is therefore not unlikely that Sortebræ overlies a potentially deformable bed. The turbid lakes further imply that a considerable amount of free water must have been trapped sub- and englacially during the surge. The presence of water may play an important role in the surge process: disruption of the subglacial drainage system has been suggested as a potential surge mechanism (Kamb, 1987). The type of substrate and its effect on subglacial drainage could affect the nature of the surge mechanism and control the propagation and termination of a surge (e.g. Dowdeswell and others, 1991; Murray and others, 2000). Lithology could therefore play an important role not only in the incidence of surging (Jiskoot and others, 2000), but also in the actual surge development.

\section{SUMMARY AND GONCLUSIONS}

Two major surges have taken place since 1933 in the Sortebræ complex. The first occurred around 1950 in Sortebræ and Bulging Tributary E, and the second occurred between 1992 and 1995 in Sortebræ. Sortebræ West appears to be permanently fast-flowing and, apart from blocking or being blocked by Sortebræ, it appears unaffected by the surges in the Sortebræ complex.

Measurement and detailed observations of the 1990s surge of Sortebræ reveal that:

1. The surge activated the lower $335 \mathrm{~km}^{2}$ of Sortebræ's basin, just under half the glacier area, redistributed $18.6 \mathrm{~km}^{3}$ of ice over the glacier, and resulted in a frontal advance of at least $5 \mathrm{~km}$ and an estimated calving flux of $3.9-7.3 \mathrm{~km}^{3} \mathrm{a}^{-1}$.

2. Measured surge velocities are in the range 1070-10 $000 \mathrm{~m}$ $\mathrm{a}^{-1}$ while quiescent-phase velocities are only $7.5-200 \mathrm{~m} \mathrm{a}^{-1}$.

3. The estimated duration of the surge phase (19-35 months) and quiescent phase ( $>40$ years) is shorter than estimated durations found for other East Greenland surge-type glaciers.

4. Crevasse patterns and surface features are similar to those found on other surging glaciers, but an unexplained phenomenon on Sortebræ is the waves on the post-surge surface in Lower Loop Basin.

5. Surge duration and velocities tentatively suggest a surge mechanism of the Alaskan type (Kamb, 1987) rather than of the Svalbard type (Murray and others, 2000).

Further research is necessary on East Greenland surgetype glaciers to elucidate the causes of diversities in surge behaviour and to explain the mechanisms of glacier surging. A detailed analysis of crevasse patterns could help reconstruct the structural processes that occurred during the surge. Measurements of velocity development during surge and quiescence would enable types of glacier surging and possible surge mechanisms to be compared. Remotely sensed data (e.g. Dwyer, 1995; Rolstad and others, 1997; Mohr and others, 1998) are excellent vehicles for this type of analysis. Murray and others (in press) make a first attempt to analyze the timing and spatial and temporal velocity development of Sortebræ's 1990s surge.

\section{ACKNOWLEDGEMENTS}

The greater part of this research was carried out during work visits of H.J. to the Department of Hydrology and Glaciology of GEUS, Copenhagen. A. Weidick, C. E. Bøggild and H. H. Thomsen made valuable contributions in discussions and in providing material. We would like to thank KMS and DLC for access to the aerial photographs and small-frame photographs, respectively, and K. Dueholm of ISP for preparing the multi-models. ERS SAR images were made available by A. Luckman, and H. Pritchard is thanked for the interferometric analysis. H.J. was funded through a School of Geography, University of Leeds, scholarship and an EULeonardo placement scheme. The constructive comments of R. Hodgkins, an anonymous reviewer and the scientific editor H. Rott helped improve this paper. 


\section{REFERENCES}

Brooks, C. K. 1979. Geomorphological observations at Kangerdlugssuaq, East Greenland. Medd. Gronl., Geoscience 1.

Colvill, A. J. 1984. Some observations on glacier surges, with notes on the Roslin glacier, East Greenland. In Miller, K. J., ed. The International Karakoram Project. Proceedings of the International Conference. Vol. 1. Cambridge, Cambridge University Press, 64-75.

Davis, J. L., J. S. Halliday and K. J. Miller. 1973. Radio echo sounding on a valley glacier in East Greenland. f. Glaciol., 12(64), 87-91.

Dolgoushin, L. D. and G. B. Osipova. 1975. Glacier surges and the problem of their forecasting. International Association of Hydrological Sciences Publication 104 (Symposium at Moscow 1971 - Snow and Ice), 292-304.

Dolgushin, L. D., S. A. Yevteyev, A. N. Krenke, K. P. Rototayev and N. M. Svatkov. 1963. Nedavneye nastupleniye lednika Medvezh'ego [The recent advance of the Medvezhii glacier]. Priroda, 11, 85-92.

Dowdeswell, J. A. 1989. On the nature of Svalbard icebergs. F. Glaciol., 35(120), 224-234

Dowdeswell, J. A., G. S. Hamilton and J. O. Hagen. 1991. The duration of the active phase on surge-type glaciers: contrasts between Svalbard and other regions. F. Glaciol., 37(127), 388-400.

Dowdeswell, J. A., R. Hodgkins, A.-M. Nuttall, J. O. Hagen and G. S. Hamilton. 1995. Mass balance change as a control on the frequency and occurrence of glacier surges in Svalbard, Norwegian High Arctic. Geophys. Res. Lett., 22(21), 2909-2912.

Dowdeswell, J. A. and 10 others. 1997. The mass balance of circum-Arctic glaciers and recent climate change. Quat. Res., 47(1), 1-14.

Dueholm, K. S. 1990. Multi-model stereo restitution. Photogramm. Eng., 56(2), 239-242.

Dueholm, K. S. 1992. Geologic photogrammetry using small-frame cameras. Gronl. Geol. Undersøgelse, Rapp. 156, 7-17.

Dueholm, K. S. and A. K. Pedersen. 1992. The application of multi-model photogrammetry in geology: status and development trends. Grønl. Geol. Undersogelse, Rapp. 156, 69-72.

Dwyer, J. L. 1995. Mapping tidewater glacier dynamics in East Greenland using Landsat data. f. Glaciol., 41 (139), 584-595.

Escher, J. C. and T. C. R. Pulvertaft. 1995. Geological map of Greenland. Copenhagen, Geological Survey of Greenland. (Scale 1:2500 000.)

Fleisher, P. J. and 6 others. 1995. Correspondence. The surging advance of Bering Glacier, Alaska, U.S.A.: a progress report. F. Glaciol., 41(137), 207-213.

Furbish, D. J. and J.T. Andrews. 1984. The use of hypsometry to indicate long-term stability and response of valley glaciers to changes in mass transfer. F. Glaciol., 30 (105), 199-211.

Gabel-Jørgensen, C. C. A. 1940. 6. og 7. Thule-expedition til Sydøstgrønland 1931-33. Leader: Knud Rasmussen. Report on the expedition. Medd. Gronl., $\mathbf{1 0 6}(1)$.

Geological Survey of Denmark and Greenland (GEUS). 1996. Topographic map of Greenland. Copenhagen, Geological Survey of Denmark and Greenland. (Sheets $68^{\circ} 01^{\prime} \mathrm{NW}, 68^{\circ} 02^{\prime} \mathrm{NE}, 69^{\circ} 02^{\prime} \mathrm{SW}$ and $69^{\circ} 03^{\prime} \mathrm{SE}$; scale $1: 100000$.)

Glasser, N. F., D. Huddart and M. R. Bennett. 1998. Ice-marginal characteristics of Fridtjovbreen (Svalbard) during its recent surge. Polar Res., 17(1), 93-100.

Hagen, J. O. 1987. Glacier surge at Usherbreen, Svalbard. Polar Res., 5(2), n.s., 239-252.

Hagen, J. O. 1988. Glacier surge in Svalbard with examples from Usherbreen. Nor. Geogr. Tidsskr., 42(4), 203-213.

Harrison, W. D., K. A. Echelmeyer, E. F. Chacho, C. F. Raymond and R. J. Benedict. 1994. The 1987-88 surge of West Fork Glacier, Susitna Basin, Alaska, U.S.A. f. Glaciol., 40(135), 241-254.

Heinrichs, T. A., L. R. Mayo, K. A. Echelmeyer and W. D. Harrison. 1996. Quiescent-phase evolution of a surge-type glacier: Black Rapids Glacier, Alaska, U.S.A. 7. Glaciol., 42(140), 110-122.

Hewitt, K. 1998. Glaciers receive a surge of attention in the Karakoram Himalaya. Eos, 79(8), 104-105.

Higgins, A. K. 1991. North Greenland glacier velocities and calf ice production. Polarforschung, 60(1), 1990, 1-23.

Hodgkins, R. and J. A. Dowdeswell. 1994. Tectonic processes in Svalbard tide-water glacier surges: evidence from structural glaciology. F. Glaciol., 40(136), 553-560.

Jiskoot, H., T. Murray and P. Boyle. 2000. Controls on the distribution of surge-type glaciers in Svalbard. f. Glaciol., 46(154), 412-422.

Joughin, I., S. Tulaczyk, M. Fahnestock and R. Kwok. 1996. A mini-surge on the Ryder Glacier, Greenland, observed by satellite radar interferometry. Science, 274(5285), 228-230.

Kamb, B. 1987. Glacier surge mechanism based on linked cavity configuration of the basal water conduit system. F. Geophys. Res., 92(B9), 9083-9100.
Kamb, B. and 7 others. 1985. Glacier surge mechanism: 1982-1983 surge of Variegated Glacier, Alaska. Science, 227(4686), 469-479.

Kirchner, G. 1963. Observations at bore holes sunk through the Schuchert Gletscher in north-east Greenland. f. Glaciol., 4(36), 817-818.

Larsen, H. C. and 6 others. 1995. The Tertiary opening of the North Atlantic: DLC investigations along the east coast of Greenland. Grønl. Geol. Undersøgelse, Rapp. 165, 106-115.

Lawson, W. 1996. Structural evolution of Variegated Glacier, Alaska, U.S.A., since 1948. 7. Glaciol., 42(141), 261-270.

Lingle, C. S., A. Post, U. C. Herzfeld, B. F. Molnia, R. M. Krimmel and J. J. Roush. 1993. Correspondence. Bering Glacier surge and iceberg-calving mechanism at Vitus Lake, Alaska, U.S.A. F. Glaciol., 39(133), 722-727.

Meier, M. F. and A. Post. 1969. What are glacier surges? Can. F. Earth Sci., 6(4), Part 2, 807-817.

Mercer, J. H. 1975. Glaciers of Greenland. In Field, W. O., ed. Mountain Glaciers of the Northern Hemisphere. Vol. 2. Hanover, NH, American Geographical Society, Department of Exploration and Field Research, and Cold Regions Research and Engineering Laboratory, U.S. Army Corps of Engineers, 755-808. (ADA 014534.)

Mohr, J.J., N. Reeh and S. N. Madsen. 1998. Three-dimensional glacial flow and surface elevation measured with radar interferometry. Nature, 391 (6664), 273-276.

Molnia, B. F. 1994. The 1993-94 surge of Bering Glacier, Alaska. Slide captions. Photographs and captions by the U.S. Geological Survey. (AGU slide set SL14.)

Murray, T., J. A. Dowdeswell, D. J. Drewry and I. Frearson. 1998. Geometric evolution and ice dynamics during a surge of Bakaninbreen, Svalbard. 7 . Glaciol., 44(147), 263-272. (Erratum: 45(150), 1999, p. 405.)

Murray, T. and 6 others. 2000. Glacier surge propagation by thermal evolution at the bed. 7. Geophys. Res., 135(B6), 13,491-13,507.

Murray, T., T. Strozzi, A. Luckman, H. Pritchard and H. Jiskoot. In press. Ice dynamics during a surge of Sortebræ, East Greenland. Ann. Glaciol., 34.

Nuttall, A.-M., J. O. Hagen and J. Dowdeswell. 1997. Quiescent-phase changes in velocity and geometry of Finsterwalderbreen, a surge-type glacier in Svalbard. Ann. Glaciol., 24, 249-254.

Olesen, O. B. and N. Reeh. 1969. Preliminary report on glacier observations in Nordvestfjord, East Greenland. Grønl. Geol. Undersøgelse, Rapp. 21, 41-53.

Olesen, O. B. and N. Reeh. 1973. Glaciological observations in the southwestern Scoresby Sund region. A preliminary report. Gronl. Geol. Undersogelse, Rapp. 58, 49-54.

Paterson, W. S. B. 1994. The physics of glaciers. Third edition. Oxford, etc., Elsevier.

Pedersen, A. K., M. Watt, W. S. Watt and L. M. Larsen. 1997. Structure and stratigraphy of the Early Tertiary basalts of the Blosseville Kyst, East Greenland. 7. Geol. Soc. London, 154(3), 565-570.

Pillmore, C. L., K. S. Dueholm, H. F. Jepsen and C. H. Schuch. 1981. Computer-assisted photogrammetric mapping system for geologic studies: a progress report. Photogrammetria, 36(5), 159-171.

Raymond, G. F. 1987. How do glaciers surge? A review. 7. Geophys. Res., 92(B9), 9121-9134.

Raymond, C., T. Jóhannesson, T. Pfeffer and M. Sharp. 1987. Propagation of a glacier surge into stagnant ice. F. Geophys. Res., 92(B9), 9037-9049.

Reeh, N., C. E. Bøggild and H. Oerter. 1994. Surge of Storstrømmen, a large outlet glacier from the inland ice of north-east Greenland. Gronl. Geol. Undersogelse, Rapp. 162, 201-209.

Rolstad, C., J. Amlien, J. O. Hagen and B. Lundén. 1997. Visible and nearinfrared digital images for determination of ice velocities and surface elevation during a surge on Osbornebreen, a tidewater glacier in Svalbard. Ann. Glaciol., 24, 255-261.

Rutishauser, H. 1971. Observations on a surging glacier in East Greenland. 7. Glaciol., 10 (58), 227-236.

Sauber, J., G. Plafker and J. Gipson. 1995. Geodetic measurements used to estimate ice transfer during Bering Glacier surge. Eos, 76 (29), 289-290.

Sharp, M., W. Lawson and R. S. Anderson. 1988. Tectonic processes in a surge-type glacier. 7. Struct. Geol., 10(5), 499-515.

Smith, A. M., T. Murray, B. M. Davison, A. F. Clough, J. Woodward and H. Jiskoot. In press. Late-surge glacial conditions on Bakaninbreen, Svalbard, and implications for surge termination. 7. Geophys. Res.

Squires, G. L. 1976. Practical physics. Second edition. Cambridge, McGraw-Hill Book Company (UK) Ltd.

Stanley, A. D. 1969. Observations on the surge of the Steele Glacier, Yukon Territory, Canada. Can. 7. Earth Sci., 6(4, Part 2), 819-830.

Sturm, M. 1987. Observations on the distribution and characteristics of potholes on surging glaciers. F. Geophys. Res., 92(B9), 9015-9022.

Weidick, A. 1988. Surging glaciers in Greenland: a status. Grønl. Geol. Undersøgelse, Rapp. 140, 106-110.

Wilbur, S.W. 1988. Surging versus non-surging glaciers: a comparison using morphometry and balance. (M.Sc. thesis, University of Alaska Fairbanks.) 